\title{
POTENSI ANTIMIKROBA FRAKSI AKTIF EKSTRAK $n$-HEKSAN DAUN RAMI (B.virgata F.) Guill TERHADAP BEBERAPA MIKROBA UJI
}

\author{
Arsyik Ibrahim \\ Fakultas Farmasi Universitas Mulawarman \\ email : achie.ibrahim@gmail.com
}

\begin{abstract}
This study aims to determine the potential antimicrobial activity of extracts soluble, insoluble $n$-hexane and fractions of $n$-hexane extract of leaves of $B$. virgata, some microbial testing with solid dilution method. Test material used was n-hexane-soluble extract $(\boldsymbol{A})$ and hexaneinsoluble (B), two extract was monitored by Thin Layer Chromatography method (TLC) chemical components, then tested its activity by solid dilution method. Test results of the antimicrobial activity of both types of extracts showed better activity than the methanol extract of soluble fraction of n-hexane and methanol extract of insoluble, because it can inhibit the growth of the bacterium E. coli, V. cholerae and S. thyposa, while the methanol extract of nhexane soluble not only able to inhibit the bacteria $V$. cholerae, at a concentration of 1000 $\mu \mathrm{g} / \mathrm{ml}$ medium. Fraction of methanol extract of $n$-hexane soluble $(\boldsymbol{A})$ is then fractionated by the method of three funel system using eluent hexane: methanol: water (20: 6: 0.5), obtained three kinds of fractions ie fraction $\boldsymbol{A}$, fraction $\boldsymbol{B}$ and fraction $\boldsymbol{C}$. The antibacterial activity tes result of fraction $\boldsymbol{A}$ is active against bacteria $V$. chilerae, $B$ fraction active against bacteria V.cholerae, S. thyposa and E. coli, and the active fractions of the yeast C.albicans $C$ respectively each active at a concentration of $750 \mu \mathrm{g} / \mathrm{ml}$ medium.
\end{abstract}

Key word: leaf B. virgata, antimicrobial, fraction soluble extracts of $n$-hexane, solid dilution

\begin{abstract}
Abstrak
Penelitian ini bertujuan untuk mengetahui potensi dan menguji aktivitas antimikroba ekstrak larut dan tidak larut $n$-heksan dan fraksi-fraksi ekstrak $n$-heksan daun B. virgata, dengan metode dilusi padat terhadap beberapa mikroba uji. Bahan uji yang digunakan adalah ekstrak larut $n$-heksan (A) dan tidak larut heksan (B), kedua ekstrak ini dimonitoring komponen kimianya dengan metode Kromatografi Lapis Tipis (KLT), kemudian diuji aktivitasnya dengan metode dilusi padat. Hasil uji aktivitas antimikroba dari kedua jenis ekstrak yang diuji, menunjukkan bahwa fraksi ekstrak metanol larut $n$-heksan memiliki aktivitas yang lebih baik dibandingkan dengan fraksi ekstrak metanol tidak larut $n$-heksan, karena dapat menghambat pertumbuhan bakteri E. coli, V. cholerae dan S. thyposa, sedangkan ekstrak metanol tidak larut $n$-heksan hanya menghambat bakteri V. cholerae, pada konsentrasi $1000 \mu \mathrm{g} / \mathrm{ml}$ medium. Fraksi ekstrak metanol larut $n$-heksan (A) difraksinasi dengan metode three funel system menggunakan eluen Heksan : metanol : air (20:6:0,5), diperoleh 3 macam fraksi yaitu fraksi $\mathbf{A}$, fraksi $\mathbf{B}$ dan fraksi C. Hasil uji aktivitas antibakteri menunjukkan fraksi A aktif terhadap bakteri V. chilerae, fraksi B aktif terhadap bakteri V.cholerae, S. thyposa dan E. coli, dan fraksi C aktif terhadap khamir C.albicans masing-masing aktif pada konsentrasi $750 \mu \mathrm{g} / \mathrm{ml}$ medium.
\end{abstract}

Kata Kunci: daun B. virgata, antimikroba, fraksi ekstrak larut $n$-heksan, dilusi padat 


\section{PENDAHULUAN}

Antimikroba ialah obat pembasmi mikroba, khususnya mikroba yang merugikan manusia. Kadar minimal yang diperlukan untuk menghambat pertumbuhan mikroba atau membunuhnya, masing-masing dikenal sebagai kadar hambat minimal (KHM) dan kadar bunuh minimal (KBM). Antimikroba tertentu aktivitasnya dapat meningkat dari bakteriostatik menjadi bakterisid bila kadar antimikrobanya ditingkatkan melebihi KHM [6].

Saat ini penyakit infeksi di Indonesia masih menjadi masalah serius di Indonesia, ditambah lagi dengan semakin meluasnya resistensi mikroba terhadap obat-obatan antimikroba lain dari bahan alam. Tanaman obat diketahui potensial untuk dikembangkan lebih lanjut [8].

Salah satu tumbuhan yang mempunyai potensi ekonomis sangat tinggi untuk dimanfaatkan adalah tumbuhan Boehmeria. Boehmeria merupakan tumbuhan dari suku Urticaceae, tumbuhan ini terdiri dari 2 jenis yaitu $B$. nivea dan $B$. virgata. $B$. nivea mengandung $\beta$-sitosterol, daucosterol dan asam $19 \alpha$-hydroksiursolik[10], selain itu mengandung zat-zat gizi diantaranya : mineral, protein, lisin dan karoten, yang hingga saat ini pemanfaatannya masih sebatas sebagai pakan ternak unggas dan babi [3].

Beberapa penelitian ilmiah tentang $B$. nivea yang telah dilaporkan diantaranya : efek antioksidan dari ekstrak air $B$. var. nivea dan var. tanacissima pada tikus yang sebelumnya telah diinduksikan dengan $\mathrm{CCl}_{4}$, dapat menurunkan kadar lipid peroksida pada hati tikus [10]. Selain itu serat Boehmeria dari spesies $B$. nivea yang diberikan pada kelinci jantan umur 44 hari dengan berat badan awal 29,85 g, konsentrasi pemberian $20 \%$ dan $40 \%$, setelah sehari pemberian berat badan kelinci turun hingga 28,95 g dan 25,60 g [5]. Penelitian antimikroba ekstrak daun Rami (Boehmeria virgata (forst.) Guill yang dilakukan Ibrahim, A., (2007), menunjukan ekstrak methanol larut nheksan memberikan aktivitas antimikroba terhadap bakteri Salmonella thyposa, Escherichia coli dan Vibrio cholerae sebesar $1000 \mu \mathrm{g} / \mathrm{mL}$ medium.

Mikroba uji yang digunakan dalam penelitian ini meliputi bakteri dan jamur. Bakteri yang digunakan adalah Bacillus subtilis, Staphylococcus aureus, Eschericia coli, Vibrio cholerae, Salmonella thyposa, dan jenis kapang/khamir yaitu Candida albicans.

Berdasarkan uraian tersebut di atas, perlu dilakukan penelitian lanjutan Pengujian potensi fraksi-fraksi ekstrak daun $B$. virgata (Forst.) (Guill.) yang memberikan aktivitas antimikroba terhadap beberap mikroba uji .

\section{METODE}

Bahan tumbuhan. Sampel yang digunakan adalah ekstrak larut $n$-heksan daun $B$. virgata, metanol teknis, $n$-hexan, kloramfenikol, dimetil sulfoksid (DMSO), ketokonazol, larutan $\mathrm{NaCl}$ fisiologis 0,9\%, medium Glukosa Nutrien Agar (GNA), alkohol $70 \%$.

Biakan Mikroba Uji : Eschericia coli, Vibrio cholerae, Salmonella thyposa, Bacillus subtilis dan Staphylococcus aureus dan 1 jenis kapang/khamir yaitu Candida albicans.

Alat-alat yang digunakan. Batang pengaduk, botol pengencer, botol semprot, cawan Petri, chamber, corong pisah, drigle sky, gelas kimia, gelas ukur, inkubator, 
labu erlenmeyer, labu tentukur, laminar air flow (LAF), lampu spiritus, lempeng KLT $\mathrm{PF}_{254}$ (E.Merck), otoklaf, oven, rotavapor, seperangkat alat sentrifuga, tabung reaksi, timbangan analitik, timbangan kasar.

Pengolahan dan Ekstraksi. Sebanyak 20,045 gram ekstrak larut n-heksan Daun $B$. virgata yang telah diketahui aktif membunuh atau menghambat pertumbuhan mikroba $1 \mathrm{mg} / \mathrm{mL}$ medium, selanjutnya dipartisi dengan campuran $n$-heksan : metanol : air $(20: 6: 0,5 \mathrm{v} / \mathrm{v})$ menggunakan metode ekstraksi three funnel system, lapisan atas dan lapisan bawah dikumpulkan dan diuapkan hingga diperoleh ekstrak kental lapisan atas (A) dan ekstrak kental lapisan bawah (B). Kedua ekstrak (A dan B) dari daun $B$. virgata dikeringkan kemudiaan diuji aktivitasnya terhadap mikroba menggunakan metode dilusi padat.

Fraksinasi dan Isolasi. Ekstrak hasil partisi three funnel system yang menunjukkan aktivitas antimikrobanya lebih baik selanjutnya difraksinasi dengan menggunakan metode isolasi Kromatografi Cair Vakum (KVC). Fraksinasi dilakukan menggunakan fase diam silika gel $\mathrm{G} 60$ dan fase gerak dengan gradien kepolaran semakin meningkat menggunakan eluen $n$ heksan, $n$-heksan : etil asetat. Fraksi-fraksi yang diperoleh selanjutnya diamati profil KLT menggunakan eluen gradien. Fraksi yang memiliki kesamaan Rf selanjutnya digabung menjadi satu fraksi.

Pengujian aktivitas antimikroba. Ekstrak hasil partisi three funnel system dan fraksifraksi hasil isolasi KVC ekstrak daun $B$. virgata diuji aktivitasnya terhadap beberapa mikroba uji dengan metode dilusi padat. Pengujian ekstrak hasil partisi three funnel system dan fraksi-fraksi hasil isolasi KVC dilakukan dengan menimbang $10 \mathrm{mg}$ ekstrak, kemudian dimasukkan ke dalam vial steril dan dilarutkan dengan $200 \mu \mathrm{L}$
(0,2 mL) DMSO dan 9,8 mL medium GNA atau PDA, diperoleh konsentrasi 1 $\mathrm{mg} / \mathrm{mL}$, dihomogenkan. Campuran ekstrak dan medium GNA dituang ke dalam cawan Petri steril dan dibiarkan memadat. Tiap cawan Petri dibagi tiga zona untuk 3 bakteri uji, dan untuk medium uji PDA dibagi 1 zona untuk khamir $C$. albicans. Setelah media memadat di tambahkan 20 $\mu \mathrm{L}$ suspensi mikroba uji. Diinkubasikan pada suhu $37{ }^{\circ} \mathrm{C}$ selama 24 jam.

Analisis Data. Analisis data akhir dari aktivitas ekstrak larut $n$-heksan dan fraksifraksi hasil isolasi ekstrak daun $B$. virgata menggunakan metode kualitatif - deskriptif dengan melihat secara visual aktivitas penghambatan dan pembunuhan bakteri uji aktivitas dari masing-masing ekstrak uji.

\section{HASIL DAN PEMBAHASAN}

\section{A. Ekstraksi Sampel}

Ekstrak metanol yang diperoleh kemudian dipekatkan menggunakan rotavapor sampai diperoleh ekstrak metanol kental, selanjutnya ekstrak kental yang diperoleh diangin-anginkan sampai ekstrak menjadi kering, ekstrak metanol kering diperoleh sebanyak 35,16 gram. Ekstrak metanol kering selanjutnya dipartisi dengan $n$ heksan dengan metode partisi padat - cair, partisi dilakukan bertujuan untuk memisahkan komponen kimia berdasarkan tingkat kepolarannya. Prinsip partisi ini pada umumnya menggunakan satu macam pelarut dengan tingkat kepolaran yang lebih rendah dari pelarut ekstrak yang dipartisi. Senyawa kimia yang sifatnya relatif non polar akan larut pada pelarut yang kepolarannya lebih rendah, sedangkan senyawa polar larut dalam pelarut yang kepolarannya lebih tinggi. Pada penelitian ini pelarut yang digunakan dengan kepolaran lebih rendah adalah $n$ heksan yang akan melarutkan senyawa 
kimia yang bersifat relatif non polar, sedangkan pelarut yang kepolarannya lebih tinggi adalah metanol yang akan melarutkan senyawa kimia yang bersifat relatif polar. Dari hasil partisi metanol diperoleh ekstrak metanol larut $n$-heksan dan ekstrak metanol tidak larut $n$-heksan dengan bobot masing-masing adalah 23,02 gram dan 8,30 gram, kedua ekstrak ini dimonitoring komponen kimianya dengan metode KLT. Hasil pengujian aktivitas antimikrobanya dari kedua ekstrak ini, ekstrak larut $n$-heksan menunjukkan aktivitas yang lebih baik dibanding ekstrak tidak larut $n$-heksan yakni pada konsentrasi $1000 \mu \mathrm{g} / \mathrm{mL}$ medium [1].

\section{B. Fraksinasi dan isolasi.}

Ekstrak larut $n$-heksan sebanyak 20,045 gram selanjutnya dipartisi lagi dengan cairan penyari $n$-heksan : metanol : air perbandingan $(20: 6: 0,5 \mathrm{v} / \mathrm{v})$ dengan corong pisah menggunakan metode three funnel system sehingga diperoleh ekstrak lapis atas (A) dan ekstrak lapis bawah (B) dengan bobot masing-masing adalah 14,599 gram dan 5,345 gram. Ekstrak lapis atas (A) dan ekstrak lapis bawah (B) selanjutnya dimonitoring komponen kimianya dengan metode KLT (Gambar 1).

Isolasi dilakukan menggunakan fase diam silika gel G 60 dan fase gerak dengan gradien kepolaran yang semakin meningkat menggunakan eluen $n$-heksan, $n$-heksan : etil asetat. Hasil isolasi diperoleh 12 fraksi, setelah dilakukan pengamatan profil KLT menggunakan fase gerak $n$ heksan : etil asetat (9:1). Fraksi yang memiliki kesamaan $\mathrm{Rf}$ selanjutnya digabung hingga diperoleh 3 fraksi gabungan yaitu fraksi A (fraksi $1-2$ ), fraksi B (fraksi 3 - 4) dan fraksi C (fraksi 5-12), (Gambar 3).

Ketiga fraksi hasil isolasi yang diperoleh selanjutnya diuji aktivitas antimikrobanya menggunakan metode dilusi padat dengan konsentrasi lebih kecil dari konsentrasi yang digunakan untuk pengujian awal yaitu $750 \mu \mathrm{g} / \mathrm{mL}$.

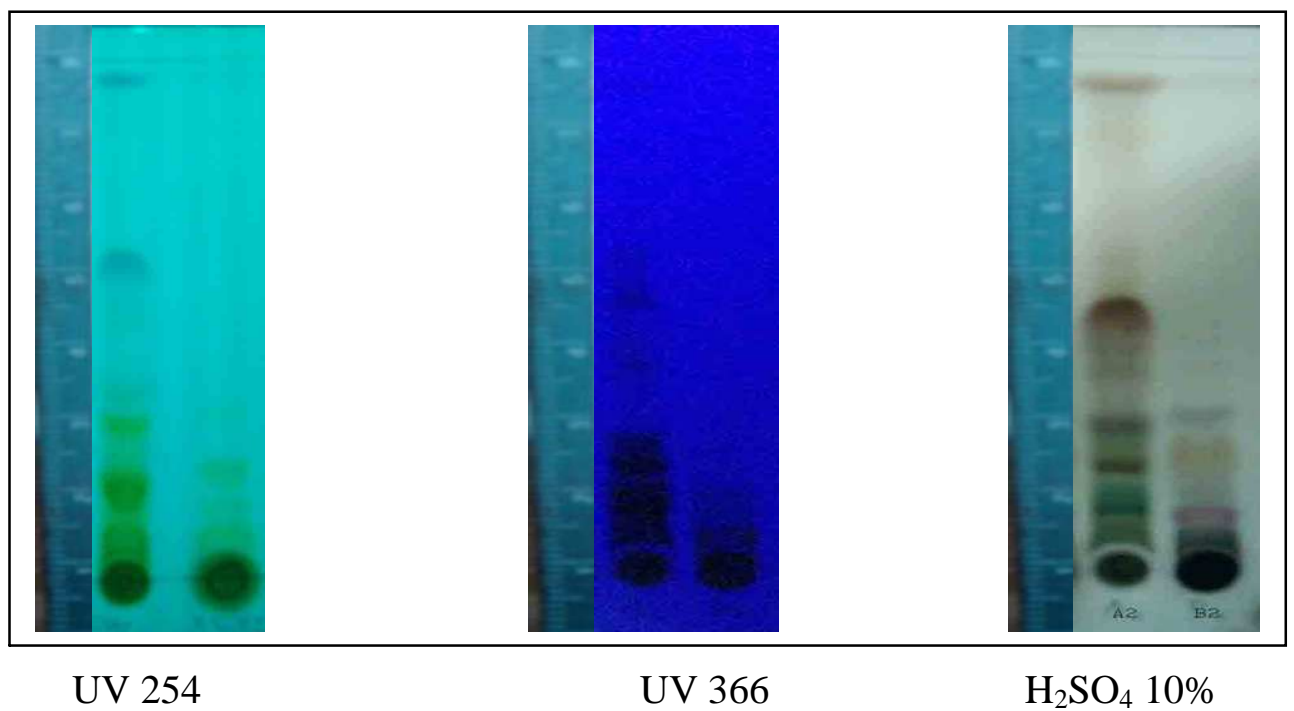

Gambar 1. Profil kromatogram ekstrak larut n-heksan (A) dan tidak larut n-heksan (B) daun B. virgata 


\section{UJI ANTIMIKROBA}

Skrining aktifitas antimikroba dilakukan terhadap bakteri Bascillus subtilis, Escherichia coli, Staphylococcus aureus, Salmonella thyposa, dan Vibrio cholera, sedangkan untuk jamur digunakan Candida albicans. Dasar pemilihan mikroba uji ini adalah karena keempatnya merupakan merupakan bakteri patogen yaitu untuk Escherichia coli, Salmonella thyposa dan Vibrio cholerae merupakan bakteri anaerobik fakultatif gram negatif yang bersifat patogenik penyebab utama diare kronik, tifoid dan kolera. Selain itu bakteri-bakteri ini dapat menyebabkan penyakit disuria akibat infeksi saluran kemih misalnya penyakit pielitis, inflamasi uregenital dan kejang uterus akibat infeksi uterus pasca persalinan oleh toksin bakteri, misalnya penyakit sepsis puerpuralis. Bacillus subtilis merupakan bakteri berbentuk basil berspora (endospora) yang bersifat gram positif dapat menyebabkan penyakit mata, infeksi kulit (luka, bisul, borok). Staphylococcus aureus merupakan bakteri kokus katalase positif gram positif yang bersifat patogenik, mikroba ini dapat menyebabkan penyakit meningitis, endokarditis, infeksi kulit (luka), keracunan makanan dan infeksi saluran kemih misalnya penyakit sistitis. Vibrio cholerae dapat menyebabkan penyakit colera, selain itu bakteri ini dapat menyebabkan penyakit gastroenteritis (radang lambung), sedangkan Candida albicans merupakan jamur yang bersifat patogenik penyebab thrush (sariawan/guam) dan vaginitis atau keputihan. [13,15].

Pengujian dilakukan dengan cara sejumlah $5 \mu \mathrm{L}$ mikroba uji diratakan di atas media agar padat dengan menggunakan alat drigalsky (metode dilusi padat). Oleh karena hasil dari metode ini diamati melalui pengamatan visual, maka ketelitian jumlah pengambilan ekstrak dan mikroba uji sangat diperlukan untuk dapat membandingkan potensi ekstrak dalam menghambat pertumbuhan mikroba.

Aktifitas antibakteri atau antijamur ditandai dengan terbentuknya zona hambatan yang bersifat radikal atau iradikal. Zona radikal tampak berupa daerah yang jernih tanpa terlihat pertumbuhan mikroba uji, sedangkan zona iradikal masih ada pertumbuhan mikroba tetapi dihambat atau pertumbuhan itu lebih kecil dibanding pertumbuhan yang tidak dihambat, oleh karena itu zona iradikal berupa zona yang keruh tetapi masih lebih jernih dibandingkan pertumbuhan di sekitarnya.

Kloramfenikol dipilih sebagai kontrol positif pada uji aktivitas antibakteri karena berspektrum luas yaitu efektif untuk bakteri gram positif dan gram negatif serta mikroorganisme yang lain, dengan mekanisme menghambat sintesis protein dengan mencegah ujung aminoasil tRNA bergabung dengan peptidil transferase (enzim yang menghubungkan asam amino dengan rantai peptida selama proses sintesis protein) [12], bersifat mudah larut dalam lemak sehingga menembus sel bakteri. Antibiotika ketokonazol digunakan sebagai kontrol positif pada uji aktivitas antijamur. Ketokonazol merupakan senyawa turunan imidazol, aktifitas antijamurnya berinteraksi dengan C-14 $\alpha$ demetilase untuk menghambat demetilase lanosterol menjadi ergosterol yang merupakan sterol penting untuk membran jamur sehingga mengganggu fungsi membran, menimbulkan ketidakteraturan membran sitoplasma jamur dan mempengaruhi biosintesis ergosterol, dan meningkatkan permeabilitas membran [12].

Berdasarkan hasil uji skrining awal, dari kedua jenis ekstrak yang diuji, ekstrak larut $n$-heksan menunjukkan aktivitas yang lebih baik dibandingkan dengan ekstrak 
tidak larut $n$-heksan, karena mampu menghambat pertumbuhan bakteri E. coli, $V$. cholerae dan $S$. thyposa, sedangkan ekstrak tidak larut n-heksan hanya mampu menghambat bakteri $V$. Cholerae sebesar $1000 \mu \mathrm{g} / \mathrm{mL}$ medium. Jadi ekstrak yang potensial untuk diisolasi dan dikembangkan dari daun $B$. virgata sebagai bahan antimikroba adalah yang terdapat pada ekstrak larut $n$-heksan.

Ekstrak $n$-heksan sebagai ekstrak aktif yang dapat membunuh/menghambat pertumbuhan mikroba $1 \mathrm{mg} / \mathrm{mL}$ medium selanjutnya dipartisi dengan campuran $n$ heksan : metonol : air (20:6:0,5 v/v) menggunakan metode ekstraksi three funnel system, lapisan atas dan lapisan bawah dikumpulkan dan diuapkan hingga diperoleh ekstrak kental lapisan atas (A) dan ekstrak kental lapisan bawah (B). Kedua ekstrak (A dan B) hasil partisi selanjutnya diuji aktivitasnya kembali (uji tahap II) (Gambar 2) dengan menggunakan konsentrasi $1000 \mu \mathrm{g} / \mathrm{mL}$ (Tabel 2).

Hasil penelitian uji aktifitas antimikroba eksrak larut n-heksan (A) tampak bahwa pada konsentrasi $1000 \mu \mathrm{g} / \mathrm{mL}$ dapat memberikan efek penghambatan dengan memberikan zona radikal pada mikroba $V$. cholerae dan memberikan zona penghambatan iradikal pada mikroba $E$. coli dan $S$. thyposa, untuk mikroba $B$. subtilis, $S$. aureus dan jamur $C$. albicans tidak memberikan zona penghambatan, sedangkan pada ekstrak tidak larut $n$ heksan (B) pada konsentrasi yang sama hanya memberikan zona penghambatan iradikal pada mikroba $S$. thyposa, sedang mikroba lainnya tidak memberikan zona penghambatan. Hasil penelitian dapat dilihat pada Gambar 2 dan Tabel 1.

Hasil pengujian ekstrak larut $n$-heksan (A) lebih aktif dibandingkan dengan ekstrak tidak larut $n$-heksan (B) hasil pengujian di atas maka penelusuran senyawa aktif dititikberatkan pada pengujian terhadap mikroba, E. coli, $S$. thyposa dan $V$. cholerae. Ekstrak lapis atas (A) selanjutnya difraksinasi dengan menggunakan metode isolasi dengan menggunakan kromatografi kolom cair vakum. Metode ini digunakan karena merupakan metode isolasi yang pengerjaanya sederhana dan dapat memisahkan senyawa kimia dalam waktu yang relatif cepat dibandingkan metode kromatografi kolom konvensional.

Fraksinasi dilakukan menggunakan fase diam silika gel G 60 dan fase gerak dengan gradien kepolaran yang semakin meningkat menggunakan eluen $n$-heksan, $n$-heksan : etil asetat. Hasil isolasi diperoleh 12 fraksi, setelah dilakukan pengamatan profil KLT menggunakan fase gerak $n$ heksan : etil asetat (9 : 1). Fraksi yang memiliki kesamaan $\mathrm{Rf}$ selanjutnya digabung hingga diperoleh 3 fraksi gabungan yaitu fraksi A (fraksi $1-2$ ), fraksi B (fraksi 3 - 4) dan fraksi C (fraksi 5-12), (Gambar 3). Ketiga fraksi yang diperoleh selanjutnya diuji aktivitas antimikrobanya menggunakan metode dilusi padat dengan konsentrasi lebih kecil dari konsentrasi yang digunakan untuk pengujian awal $(750 \mu \mathrm{g} / \mathrm{mL})$, dari hasil pengujian aktivitas antimikrobanya, fraksi B lebih aktif dibandingkan dengan fraksi A dan C (Gambar 3). 


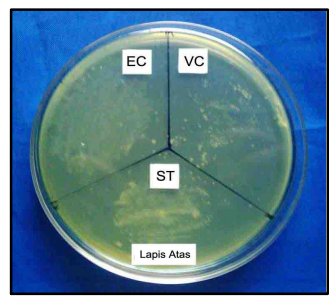

A1

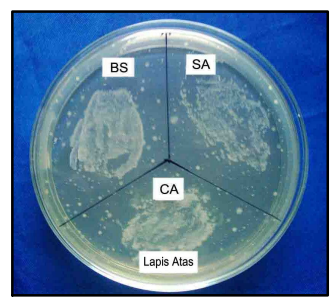

A2

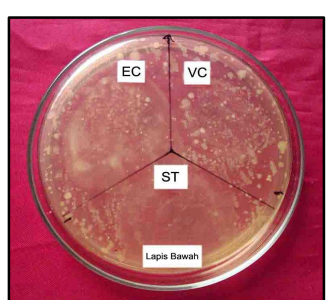

B1

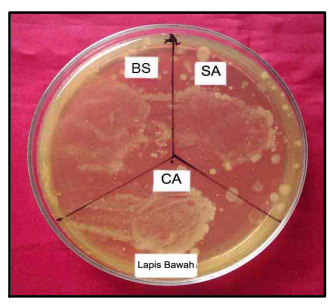

B2

Gambar 2. Aktivitas antimikroba ekstrak ekstrak larut n-heksan (A) dan ekstrak tidak n-heksan (B) kosentrasi $1000 \mu \mathrm{g} / \mathrm{ml}$

Keterangan :

A1, A2 : ekstrak larut n-heksan (A)

B1, B2 : ekstrak tidak larut n-heksan $(B)$

EC : Escherichia coli

VC : Vibrio cholerae

ST : Salmonella thyposa

BS $\quad$ : Bacillus subtilis

SA $\quad:$ Staphylococcus aureus

CA : Candida albicans

Medium : Glukosa Nutrien Agar (GNA)

Waktu inkubasi : $1 \times 24$ jam; $37^{\circ} \mathrm{C}$ (bakteri)

: $2 \times 24$ jam; (khamir)

Tabel 1. Hasil uji aktivitas antimikroba ekstrak larut n-heksan (A) dan tidak larut n-heksan (B) pada konsentrasi $1000 \mu \mathrm{g} / \mathrm{ml}$

\begin{tabular}{cllccccc}
\hline \multirow{2}{*}{ Sampel } & \multicolumn{1}{c}{ Ekstrak } & \multicolumn{7}{c}{ Mikroba Uji } \\
\cline { 2 - 7 } B. virgata & larut n-heksan (A) & ++ & + & + & - & - & - \\
\multirow{2}{*}{ Kontrol } & tidak larut n-heksan (B) & - & + & - & - & - & - \\
& K+ (antibakteri) & ++ & ++ & ++ & ++ & ++ & - \\
& K+ (antijamur) & - & - & - & - & - & ++ \\
& K- (DMSO) & - & - & - & - & - & - \\
\end{tabular}

Keterangan

VC : Vibrio cholerae

ST : Salmonella thyposa

EC : Escherichia coli

SA : Staphylococcus aureus

$K+$ (antibakteri) $\quad:$ Kontrol positif antibakteri (kloramfenikol)

K+ (antijamur) $\quad:$ Kontrol positif antijamur (ketokonazol)

$++\quad:$ Menghambat pertumbuhan mikroba

$+\quad$ : Kurang menghambat pertumbuhan mikroba

- $\quad$ : Tidak menghambat pertumbuhan mikroba 


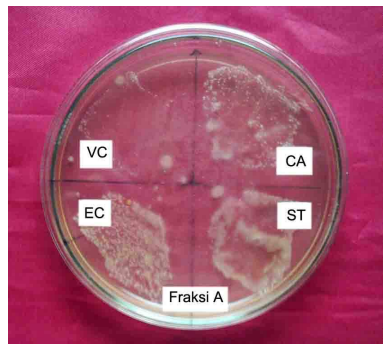

A

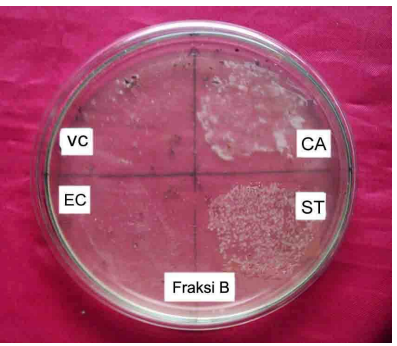

B

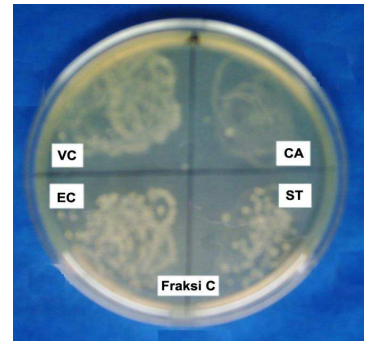

C

Gambar 3. Aktivitas antimikroba fraksi-fraksi hasil isolasi ekstrak lapis atas daun B. virgata kosentrasi $750 \mu \mathrm{g} / \mathrm{ml}$

Keterangan :

$\begin{array}{ll}\text { Fraksi } & : \text { A, B dan C } \\ \text { EC } & : \text { Escherichia coli } \\ \text { VC } & : \text { Vibrio cholerae } \\ S T & : \text { Salmonella thyposa } \\ \text { CA } & : \text { Candida albicans } \\ \text { Medium } & : \text { Glukosa Nutrien Agar (GNA) } \\ \text { Waktu inkubasi } & : 1 \times 24 \text { jam; } 37^{\circ} \text { C (bakteri) } \\ & : 2 \times 24 \text { jam; khamir) }\end{array}$

Tabel 2. Hasil uji aktivitas antimikroba fraksi -fraksi hasil isolasi pada konsentrasi $750 \mu \mathrm{g} / \mathrm{ml}$

\begin{tabular}{cccccc}
\hline \multirow{2}{*}{ Sampel } & \multirow{2}{*}{ Nama ekstrak } & \multicolumn{5}{c}{ Mikroba Uji } \\
\cline { 3 - 6 } B. virgata & Fraksi A & VC & ST & EC & CA \\
& Fraksi B & + & - & - & - \\
\multirow{3}{*}{ Kontrol } & Fraksi C & - & + & ++ & - \\
& $\mathrm{K}+($ antibakteri) & ++ & ++ & ++ & + \\
& $\mathrm{K}+($ antijamur) & - & - & - & ++ \\
& $\mathrm{K}-($ DMSO) & - & - & - & - \\
\hline
\end{tabular}

Sifat fisik senyawa aktif yang terdapat dalam fraksi A dan $\mathbf{B}$ tersebut bersifat mudah larut dalam lemak sehingga memiliki kemampuan menembus sel bakteri, senyawa tersebut diduga bekerja dengan menghambat sintesis protein dengan mencegah ujung aminoasil tRNA bergabung dengan peptidil transferase (enzim yang menghubungkan asam amino dengan rantai peptida selama proses sintesis protein) [12]. Fraksi C efektif terhadap khamir C. albicans, mekanisme aktifitas antijamurnya berinteraksi dengan C-14 $\alpha$-demetilase untuk menghambat demetilase lanosterol menjadi ergosterol yang merupakan sterol penting untuk membran jamur sehingga mengganggu fungsi membran, menimbulkan ketidakteraturan membran sitoplasma jamur dan mempengaruhi biosintesis ergosterol, dan meningkatkan permeabilitas membran [12]. 


\section{KESIMPULAN DAN SARAN}

\section{A. KESIMPULAN}

1. Ekstrak metanol larut $n$-heksan (A) memiliki aktivitas antimikroba paling tinggi pada konsentrasi $1000 \mu \mathrm{g} / \mathrm{mL}$ terhadap bakteri Eschericia coli, Vibrio cholerae dan Salmonela thyposa dibandingkan ekstrak metanol tidak larut $n$-heksan (B)

2. Potensi antibakteri fraksi $\mathbf{A}$ hasil isolasi ekstrak $n$-heksan daun $B$. virgata adalah $750 \mu \mathrm{g} / \mathrm{mL}$ terhadap bakteri Vibrio cholerae

3. Potensi antibakteri fraksi $\mathbf{B}$ hasil isolasi ekstrak $n$-heksan daun $B$. virgata adalah $750 \mu \mathrm{g} / \mathrm{mL}$ terhadap bakteri Vibrio cholerae, Salmonela thyposa dan Eschericia coli.

4. Potensi antijamur fraksi $\mathbf{C}$ hasil isolasi ekstrak $n$-heksan daun $B$. virgata adalah $750 \mu \mathrm{g} / \mathrm{mL}$ terhadap khamir Candida albicans.

\section{B. SARAN}

Isolasi dan Identifikasi lebih lanjut senyawa aktif daun $B$. virgata dengan menggunakan data KLT-bioautografi, reagen kimia, Ultraviolet, Infra Merah, Spektra Massa, ${ }^{1-} \mathrm{H}-\mathrm{NMR}$ dan ${ }^{13-} \mathrm{C}-\mathrm{NMR}$ untuk penentuan strukturnya.

\section{UCAPAN TERIMA KASIH}

Ucapan terima kasih kepada Pimpinan Fakultas UP. Fakultas Farmasi yang telah memberikan dana penelitian, dan kepada kepala Laboratorium Biologi dan Mikrobiologi dan Laboratorium Bahan Alam UP. Fakultas Farmasi UNMUL yang telah memberikan izin menggunakan laboratorium untuk penelitian.

\section{DAFTAR PUSTAKA}

1. Ibrahim, A. 2011. Aktivitas Antimikroba Ektrak Daun Rami (Boehmeria virgata (Forst.) Guill terhadap Beberapa Mikroorganisme. Journal of Tropical Pharmacy and Chemistry. Vol. 1 No. 2 : 86-93)

2. Brink. M.; \& Escobin. R.P. 2003. Plant Resources of South - East Asia. Fiber Plants. Backhuys Publishers. Leiden. 86 - 91.

3. Cheeke, P.R. 1987. Rabbit Feeding and Nutrition. Academic Press Inc. Orlando. 376 (online).

4. Djide, N.M. 2008. Analisis Mikrobiologi Farmasi. Jurusan Farmasi F.MIPA. Universitas Hasanuddin : Makassar. 295 - 301.

5. Gabbia, A. M.; Vegas, J.; Toledo, S.; Iora, A.; Fronza, L.; \& Carlotto,S. 2002. Increasing Level of Ramie (Boehmeria nivea) Hay on the Diets of Fattening Rabbits. Journal Application Rabbit. Vol. 97 : 105 - 900. (online).

6. Ganiswara, S. 1995. Farmakologi dan Terapi. Edisi IV. Bagian Farmakologi Fakultas Kedokteran Universitas Indonesia. Jakarta. 572 - 573.

7. Gritter, R.J.; Bobbit, J.M.; \& Schwarting, A.E. 1991. Pengantar Kromatografi. Edisi II. Penerbit ITB. Bandung. 1, 14, 114 -115.

8. Hertiani, T. 2003. Uji In Vitro Potensi Antimikroba Terhadap Staphylococcus aureus Eschericia coli, Shigella dysentriae dan Candida albicans dari Beberapa Tanaman Obat Tradisional Untuk Penyakit Infeksi. Jurnal Farmasi Indonesia Pharmacon. Volume 4 (2), Surakarta. 2003.

9. Jawetz, M.; \& Adelbergs's. 2001. Mikrobiologi Kedokteran. Terjemahan Staf Pengajar Bagian Mikrobiologi Fakultas Kedokteran. Universitas Airlangga. Salemba Medika. Jakarta. 224 - 228.

10. Lin, C.C; Yen, M.H.; Lo, T.S.; \& Lin, J.M. 1998. Evaluation of the Hepatoprotective and Antioxidant Activity of Boehmeria nivea var. nivea and $B$. nivea var.

11. Mendes, A.A.; Funari, S.R.C.; Nunes, J.R.V.; \& Spers, A. 1980. Increasing Levels of Rami Hay in Rations for Rabbits in Development. Journal Application Rabbit. Vol. 1 : 27 - 35 (online).

12. Olson, J. 2004. Belajar Mudah Farmakologi. Cetakan 1. EGC Penerbit Buku Kedokteran. Jakarta.

13. Syahrurrahman, A.; Chatim, A.; Subandrio, A.; Karuniawati, A.; Triyatni, R.M.; Utji, R.; \& Sardjito, R. 1994. Mikrobiologi Kedokteran. Edisi Revisi. Binarupa Aksara. Jakarta. 7 - 10, 163. 
Potensi antimikroba fraksi aktif ekstrak n-heksan daun rami (B.virgataf.) Guill terhadap beberapa mikroba uji

14. Stahl, E. 1969. Thin Layer Chromatography. $2^{\text {nd }}$ edition. Springer Verlag. Berlin. Heidelberg. New York. 650-654.
15. Strohl, W.; et al. 2001. Lippincott's Illustrated Reviews: Microbiology. Lippincott Williams \& Wilkins. A Walters Kluwer Company. Baltimore. Maryland. USA. 4 